\title{
Equilibrium and Kinetic Investigations of the Interaction of Model Platinum(II) Complex with DNA Constituents in Reference to the Antitumour Activity: Complex-Formation Reactions of $\left[\mathbf{P d}(\mathbf{N}, \mathbf{N} \text {-diethylethylenediamine })\left(\mathrm{H}_{2} \mathrm{O}\right)_{2}\right]^{2+}$ with Ligands of Biological Significance and Displacement Reactions of DNA Constituents
}

\author{
Eman Mohamed Shoukry \\ Department of Chemistry, Faculty of Science, Taif University, 21974 Taif, Saudi Arabia \\ Correspondence should be addressed to Eman Mohamed Shoukry, eman_shoukry2002@hotmail.com
}

Received 27 April 2009; Accepted 11 June 2009

Recommended by Imre Sovago

The $\left[\mathrm{Pd}(\mathrm{DEEN}) \mathrm{Cl}_{2}\right]$ and $\left[\mathrm{Pt}(\mathrm{DEEN}) \mathrm{Cl}_{2}\right]$ complexes were synthesized and characterized where DEEN = N,N-diethylethylenediamine. The stoichiometry and stability of the complexes formed between various biologically relevant ligands (amino acids, peptides, DNA constituents and dicarboxylic acids) and $\left[\mathrm{Pd}(\mathrm{DEEN})\left(\mathrm{H}_{2} \mathrm{O}\right)_{2}\right]^{2+}$ were investigated at $37^{\circ} \mathrm{C}$ and $0.16 \mathrm{M}$ ionic strength. The stability constant of the complexes formed in solution were determined and the binding centres of the ligands were assigned. The concentration distribution diagrams of the complexes were evaluated The equilibrium constants for the displacement of representative coordinated ligands such as inosine, glycine or methionine by cysteine were calculated and the concentration distribution diagrams of the various species were evaluated. The kinetics of base hydrolysis of free and coordinated S-methylcysteine methyl ester was investigated. The mechanism of hydrolysis was discussed.

Copyright () 2009 Eman Mohamed Shoukry. This is an open access article distributed under the Creative Commons Attribution License, which permits unrestricted use, distribution, and reproduction in any medium, provided the original work is properly cited.

\section{Introduction}

Cis-platin [cis-diamminedichloroplatinum(II)] is one of the most active antitumour agents in clinical use [1]. However, it has a narrow spectrum of activity, and its clinical use is limited by undesirable side effects, including nephrotoxicity, ototoxicity, neurotoxicity, nausea, vomiting, and myelosuppression $[2,3]$. In the search for new platinum anticancer drugs, great efforts are devoted to the design of complexes more efficient and less toxic than the reference drugs already in clinical use. For this purpose, the rational design of complexes and the study of relevant structureactivity relationships have been extended to families of new compounds having high structural diversity.

$\mathrm{Pd}(\mathrm{II})$ and $\mathrm{Pt}(\mathrm{II})$ amine complexes have the same structure, with a five orders of magnitude higher reactivity in the case of Pd(II) complexes, but similar thermodynamic parameters. Pd(II) complexes are good models for the analogous $\mathrm{Pt}$ (II) complexes in solution. Recent work in our laboratories focused on the equilibria of complex-formation reactions of cis-(diamine)palladium(II) complexes with DNA, the major target in chemotherapy of tumours, and biorelevant ligands as amino acids, peptides, dicarboxylic acids, and esters [4$10]$. In the present project we have synthesised and characterised the $\left[\mathrm{Pt}(\mathrm{DEEN}) \mathrm{Cl}_{2}\right]$ and $\left[\mathrm{Pd}(\mathrm{DEEN}) \mathrm{Cl}_{2}\right]$ complexes. The thermodynamic behaviour of the $\mathrm{Pd}(\mathrm{II})$ complex was investigated. The amine investigated has two ethyl groups attached to one nitrogen atom of ethylenediamine. The two ethyl groups will create steric hinderence with the incoming ligand as DNA. This will tune the reactivity of the complex to be similar to the antitumour platinum-amine complex. The equilibrium studies are conducted at $37^{\circ} \mathrm{C}$ and ionic 
strength $0.16 \mathrm{M}$. This condition is similar to what is exist in biological fluids. The sulphur ligands as cysteine or glutathione have high affinity for $\mathrm{Pd}(\mathrm{II})$ and $\mathrm{Pt}(\mathrm{II})$ complexes. These ligands will compete with the DNA for the reaction with any antitumour agent. Therefore, it is of biological significance to evaluate the equilibrium constants for the displacement reaction of model ligands as inosine, glycine, or methionine by cysteine. These equilibrium constants may give a measure of the effectiveness of the antitumour agent.

\section{Experimental}

2.1. Materials. $\mathrm{K}_{2} \mathrm{PdCl}_{4}, \mathrm{~K}_{2} \mathrm{PtCl}_{4}, \mathrm{~N}, \mathrm{~N}$-diethylethylendiamine, and cyclobutanedicarboxylic acid were obtained from Aldrich. The amino acids and related compounds (glycine, alanine, $\beta$-alanine, $\gamma$-aminobuteric acid, $\beta$-phenylalanine, valine, proline, hydroxyproline, iso-leucine, ethanolamine $\mathrm{HCl}$, serine, histidine, histamine dihydro-chloride, ornithine, lysine, cysteine, methionine, threonine, Smethylcysteine, aspartic acid glutamic acid, and methylamine $\cdot \mathrm{HCl}$ ) were provided by Sigma Chemical Co. The peptides used (glycinamide, glycylglycine, glycylleucine, asparagines, and glutamine) and the dibasic acids used (cyclobutane dicarboxylic acid, malonic acid, oxalic acid, succinic acid, adipic acid, and fumaric acid) were all provided by BDH-Biochemicals Ltd, Poole, UK. The DNA constituents (inosine, inosine $5^{\prime}$-monophosphate, adenine, guanosine, guanosine $5^{\prime}$-monophosphate, adenosine, cytosine,thymidine, cytidine $5^{\prime}$-monophosphate, uracil, and uridine $5^{\prime}$-monophosphate) were provided by Sigma Chemical Co. S-methylcysteine methyl ester was obtained from Sigma Chem. Co. For equilibrium studies, $\left[\mathrm{Pd}(\mathrm{DEEN}) \mathrm{Cl}_{2}\right]$ was converted into the diaqua complex by treating it with two equivalents of $\mathrm{AgNO}_{3}$ as described before [11]. The ligands in the form of hydrochlorides were converted into the corresponding hydronitrates. Cytosine, guanosine, and the nucleotides were prepared in the protonated form with standard $\mathrm{HNO}_{3}$ solution. All solutions were prepared in deionized water.

2.2. Synthesis. $\left[\mathrm{Pd}(\mathrm{DEEN}) \mathrm{Cl}_{2}\right]$ was prepared by dissolving $\mathrm{K}_{2} \mathrm{PdCl}_{4}(2.82 \mathrm{mmol})$ in $10 \mathrm{~mL}$ water with stirring. The clear solution of $\left[\mathrm{PdCl}_{4}\right]^{2-}$ was filtered, and N,N-diethylethylenediamine $(2.82 \mathrm{mmol})$, dissolved in $10 \mathrm{~mL} \mathrm{H}_{2} \mathrm{O}$, was added dropwise to the stirred solution. The $\mathrm{pH}$ was adjusted to 2-3 by the addition of $\mathrm{HCl}$ and/or $\mathrm{NaOH}$. A yellowishbrown precipitate of $\left[\mathrm{Pd}(\mathrm{DEEN}) \mathrm{Cl}_{2}\right]$ was formed and stirred for a further 30 minute at $50{ }^{\circ} \mathrm{C}$. After filtering off the precipitate, it was thoroughly washed with $\mathrm{H}_{2} \mathrm{O}$, ethanol, and diethylether. A yellow powder was obtained. Anal. Calcd. for $\mathrm{C}_{6} \mathrm{H}_{16} \mathrm{~N}_{2} \mathrm{PdCl}_{2}$ : C, 24.54; $\mathrm{H}, 5.45 ; \mathrm{N}, 9.54$. Found: $\mathrm{C}$, $24.51 ; \mathrm{H}, 5.46 ; \mathrm{N}, 9.44$. The IR spectrum of $\mathrm{Pd}(\mathrm{DEEN}) \mathrm{Cl}_{2}$ exhibits strong $\mathrm{NH}$ absorption band in the range 3113$3207 \mathrm{~cm}^{-1} . \delta(\mathrm{NH})$ bands are observed at $1580-1609 \mathrm{~cm}^{-1}$. The Pd-N absorption was detected at $439 \mathrm{~cm}^{-1}$. The chloro complex was converted into the corresponding aqua complex in solution by addition of two equivalents of $\mathrm{AgNO}_{3}$, heating to $40-50{ }^{\circ} \mathrm{C}$ for 3 hours, and removing the precipitated $\mathrm{AgCl}$ by filteration.

$\left[\mathrm{Pt}(\mathrm{DEEN}) \mathrm{Cl}_{2}\right]$ was prepared by dissolving $\mathrm{K}_{2} \mathrm{PtCl}_{4}$ $(2 \mathrm{mmol})$ in $10 \mathrm{~mL}$ water with stirring. The clear solution of $\left[\mathrm{PtCl}_{4}\right]^{2-}$ was filtered, and $\mathrm{N}, \mathrm{N}$-diethylethylenediamine $(2 \mathrm{mmol})$, dissolved in $10 \mathrm{~mL}$ water, was added dropwise to the stirred solution. The solution mixture was refluxed at $70{ }^{\circ} \mathrm{C}$ for 6 hours. The solution is evaporated to $5 \mathrm{~mL}$. A yellow precipitate of $\left[\mathrm{Pt}(\mathrm{DEEN}) \mathrm{Cl}_{2}\right]$ is formed. The precipitate is filtered, thoroughly washed with water, ethanol, and diethylether. Anal. Calcd for $\mathrm{C}_{6} \mathrm{H}_{16} \mathrm{~N}_{2} \mathrm{PtCl}_{2} \cdot \mathrm{H}_{2} \mathrm{O}: \mathrm{C}$, 17.99; H,4.50; N, 7.00. Found: C, 18.69; H,4.24; N, 6.95\%. The IR spectrum of $\left[\mathrm{Pt}(\mathrm{DEEN}) \mathrm{Cl}_{2} \cdot \mathrm{H}_{2} \mathrm{O}\right]$ exhibits strong bands $\left(\mathrm{H}_{2} \mathrm{O}\right)$ in the range $3479-3544 \mathrm{~cm}^{-1}$, strong $\mathrm{NH}$ absorption band in the range $3128-3239 \mathrm{~cm}^{-1} . \delta(\mathrm{NH})$ band is observed at $1608 \mathrm{~cm}^{-1}$. The Pt-N absorption was detected at $441 \mathrm{~cm}^{-1}$.

2.3. Apparatus. Potentiometric titrations were performed with a Metrohm 686 titroprocessor equipped with a 665 Dosimat. The titroprocessor and electrode were calibrated with standard buffer solutions, prepared according to NBS specification [12]. All titrations were carried out at $37.0 \pm$ $0.1^{\circ} \mathrm{C}$ in purified nitrogen atmosphere using a titration vessel described previously [13]. IR spectra were measured on a 8001-PC FT-IR Shimadzu spectrophotometer using $\mathrm{KBr}$ pellets.

2.4. Procedure and Measuring Technique. The acid dissociation constants of the ligands were determined by titrating $1.00 \mathrm{mmol}$ samples of each with standard $\mathrm{NaOH}$ solutions. Ligands were converted into their protonated form with standard $\mathrm{HNO}_{3}$ solutions. The acid dissociation constants of the coordinated water molecules in $\left[\mathrm{Pd}(\mathrm{DEEN})\left(\mathrm{H}_{2} \mathrm{O}\right)_{2}\right]^{2+}$ were determined by titrating $1.00 \mathrm{mmol}$ of complex with standard $0.05 \mathrm{M} \mathrm{NaOH}$ solution. The formation constants of the complexes were determined by titrating solution mixtures of $\left[\mathrm{Pd}(\mathrm{DEEN})\left(\mathrm{H}_{2} \mathrm{O}\right)_{2}\right]^{2+}(1.00 \mathrm{mmol})$ and the ligand in the concentration ratio of $1: 1$ for amino acids, peptides, and dicarboxylic acids and in the ratio of $1: 2$ (Pd:ligand) for the DNA constituents. The titrated solution mixtures each had a volume of $40 \mathrm{~mL}$, and the titrations were carried out at $37^{\circ} \mathrm{C}$ and $0.1 \mathrm{M}$ ionic strength (adjusted with $\mathrm{NaNO}_{3}$ ). A standard $0.05 \mathrm{M} \mathrm{NaOH}$ solution was used as titrant. The $\mathrm{pH}$ metre readings were converted to hydrogen ion concentration by titrating a standard $\mathrm{HNO}_{3}$ solution $(0.01 \mathrm{M})$, the ionic strength of which was adjusted to $0.1 \mathrm{M}$ with $\mathrm{NaNO}_{3}$, with standard $\mathrm{NaOH}(0.05 \mathrm{M})$ at $37^{\circ} \mathrm{C}$. The $\mathrm{pH}$ was plotted against $\mathrm{p}[\mathrm{H}]$. The relationship $\mathrm{pH}-\mathrm{p}[\mathrm{H}]=$ 0.05 was observed.

The species formed were characterized by the general equilibrium

$$
\mathrm{pM}+\mathrm{qL}+\mathrm{rH} \rightleftharpoons(\mathrm{M})_{\mathrm{p}}(\mathrm{L})_{\mathrm{q}}(\mathrm{H})_{\mathrm{r}},
$$

for which the formation constants are given by

$$
\beta_{\mathrm{pqr}}=\frac{\left[(\mathrm{M})_{\mathrm{p}}(\mathrm{L})_{\mathrm{q}}(\mathrm{H})_{\mathrm{r}}\right]}{[\mathrm{M}]^{\mathrm{p}}[\mathrm{L}]^{\mathrm{q}}[\mathrm{H}]^{\mathrm{r}}},
$$


TABLE 1: Formation constants for complexes of $\left[\operatorname{Pd}(\mathrm{DEEN})\left(\mathrm{H}_{2} \mathrm{O}\right)_{2}\right]^{2+}$ with amino acids at $37^{\circ} \mathbf{C}$ and $0.16 \mathrm{M}$ ionic strength.

\begin{tabular}{|c|c|c|c|c|c|}
\hline Ligand & $\mathrm{MLH}^{\mathrm{a}}$ & $\log \beta^{\mathrm{b}}$ & Ligand & $\mathrm{ML} \mathrm{H}^{\mathrm{a}}$ & $\log \beta^{b}$ \\
\hline \multirow[t]{3}{*}{$\mathrm{OH}^{-}$} & $10-1$ & $-5.11(0.01)$ & Glycine & 011 & $9.20(0.02)$ \\
\hline & $10-2$ & $-14.80(0.02)$ & & 012 & $11.20(0.03)$ \\
\hline & $20-2$ & $-7.20(0.04)$ & & 110 & $10.33(0.02)$ \\
\hline \multirow[t]{3}{*}{ Alanine } & 011 & $9.27(0.01)$ & $\beta$-Phenylalanine & 011 & $9.12(0.01)$ \\
\hline & 012 & $12.17(0.02)$ & & 012 & $11.01(0.03)$ \\
\hline & 110 & $10.16(0.02)$ & & 110 & $9.86(0.02)$ \\
\hline \multirow[t]{3}{*}{$\gamma$-Aminobutyric acid } & 011 & $9.63(0.00)$ & $\beta$-Alanine & 011 & $9.70(0.02)$ \\
\hline & 012 & $13.10(0.02)$ & & 012 & $13.20(0.03)$ \\
\hline & 110 & $7.61(0.02)$ & & 110 & $9.50(0.02)$ \\
\hline \multirow[t]{3}{*}{ Valine } & 011 & $9.01(0.01)$ & Proline & 011 & $10.06(0.01)$ \\
\hline & 012 & $11.48(0.02)$ & & 012 & $11.81(0.05)$ \\
\hline & 110 & $9.90(0.03)$ & & 110 & $10.51(0.10)$ \\
\hline \multirow[t]{3}{*}{ Iso-Leucine } & 011 & $9.46(0.01)$ & Histamine & 011 & $9.34(0.01)$ \\
\hline & 012 & $11.74(0.02)$ & & 012 & $15.20(0.02)$ \\
\hline & 110 & $10.40(0.02)$ & & 110 & $12.85(0.08)$ \\
\hline \multirow[t]{5}{*}{ Histidine } & 011 & $8.84(0.01)$ & Ethanolamine & 011 & $9.16(0.01)$ \\
\hline & 012 & $14.74(0.02)$ & & 110 & $6.99(0.02)$ \\
\hline & 013 & $16.81(0.06)$ & & 120 & $12.00(0.04)$ \\
\hline & 110 & $13.37(0.01)$ & & $11-1$ & $2.01(0.04)$ \\
\hline & 111 & $16.32(0.03)$ & & & $\left(\mathrm{pk}^{\mathrm{H}}=4.98\right)$ \\
\hline \multirow[t]{5}{*}{ Serine } & 011 & $8.59(0.01)$ & Threonine & 011 & $8.79(0.01)$ \\
\hline & 012 & $10.95(0.02)$ & & 012 & $10.85(0.02)$ \\
\hline & 110 & $10.01(0.01)$ & & 110 & $9.98(0.07)$ \\
\hline & $11-1$ & $2.04(0.02)$ & & $11-1$ & $2.10(0.08)$ \\
\hline & & $\left(\mathrm{pk}^{\mathrm{H}}=7.97\right)$ & & & $\left(\mathrm{pk}^{\mathrm{H}}=7.88\right)$ \\
\hline \multirow[t]{5}{*}{ Ornithine } & 011 & $9.81(0.02)$ & Lysine & 011 & $9.90(0.02)$ \\
\hline & 012 & $18.16(0.02)$ & & 012 & $18.80(0.03)$ \\
\hline & 013 & $20.01(0.03)$ & & 013 & $21.00(0.03)$ \\
\hline & 110 & $12.90(0.05)$ & & 110 & $10.12(0.05)$ \\
\hline & 111 & $20.10(0.04)$ & & 111 & $18.70(0.02)$ \\
\hline \multirow[t]{5}{*}{ Aspartic acid } & 011 & $9.31(0.02)$ & Glutamic acid & 011 & $9.34(0.02)$ \\
\hline & 012 & $12.79(0.03)$ & & 012 & $13.15(0.03)$ \\
\hline & 013 & $14.50(0.03)$ & & 013 & $15.73(0.05)$ \\
\hline & 110 & $8.53(0.03)$ & & 110 & $8.70(0.03)$ \\
\hline & 111 & $11.92(0.04)$ & & 111 & $11.87(0.02)$ \\
\hline \multirow[t]{3}{*}{ S-methylcysteine methyl ester } & 011 & $8.51(0.02)$ & Methionine & 011 & $8.76(0.02)$ \\
\hline & 012 & $10.40(0.02)$ & & 012 & $11.00(0.03)$ \\
\hline & 110 & $9.51(0.01)$ & & 110 & $9.32(0.04)$ \\
\hline \multirow[t]{3}{*}{ Hydroxyproline } & 011 & $9.20(0.01)$ & Methylamine & 011 & $9.32(0.01)$ \\
\hline & 012 & $11.00(0.02)$ & & 110 & $7.11(0.06)$ \\
\hline & 110 & $9.91(0.03)$ & & 120 & $12.53(0.04)$ \\
\hline
\end{tabular}


Table 1: Continued.

\begin{tabular}{|c|c|c|c|c|c|}
\hline Ligand & $\mathrm{MLH}^{\mathrm{a}}$ & $\log \beta^{\mathrm{b}}$ & Ligand & $\mathrm{M} \mathrm{L} \mathrm{H}^{\mathrm{a}}$ & $\log \beta^{\mathrm{b}}$ \\
\hline \multirow[t]{5}{*}{ Cysteine } & 011 & $10.00(0.01)$ & & & \\
\hline & 012 & $18.21(0.02)$ & & & \\
\hline & 013 & $19.62(0.02)$ & & & \\
\hline & 110 & $14.11(0.03)$ & & & \\
\hline & & $18.20(0.04)$ & & & \\
\hline
\end{tabular}

${ }^{\mathrm{a}} \mathrm{M}, \mathrm{L}$, and $\mathrm{H}$ are the stoichiometric coefficients corresponding to $\mathrm{Pd}(\mathrm{DEEN})$, amino acid, and $\mathrm{H}^{+}$, respectively; the coefficient -1 , refers to a proton loss. ${ }^{\mathrm{b}} \log \beta$ of $\mathrm{Pd}(\mathrm{DEEN})$-amino acids. Standard deviations are given in parentheses; sum of square of residuals are less than $5 \mathrm{E}-7, \mathrm{pK} \mathrm{H}^{\mathrm{H}}=\log \beta_{110}-\log \beta_{11-1}$.

TABLE 2: Formation constants for complexes of $\left[\mathrm{Pd}(\mathrm{DEEN})\left(\mathrm{H}_{2} \mathrm{O}\right)_{2}\right]^{2+}$ with peptides, dibasic acids, and DNA units at $37^{\circ} \mathrm{C}$ and $0.16 \mathrm{M}$ ionic strength.

\begin{tabular}{|c|c|c|c|c|c|}
\hline Ligand & $\mathrm{ML} \mathrm{H}^{\mathrm{a}}$ & $\log \beta^{\mathrm{b}}$ & Ligand & $\mathrm{M} \mathrm{L} \mathrm{H}^{\mathrm{a}}$ & $\log \beta^{\mathrm{b}}$ \\
\hline \multirow[t]{5}{*}{ Glycinamide } & & & Cyclobutane-1,1- dicarboxylic acid & & \\
\hline & 011 & $7.50(0.02)$ & & 011 & $5.37(0.01)$ \\
\hline & 110 & $7.81(0.02)$ & & 012 & $8.17(0.01)$ \\
\hline & $11-1$ & $4.16(0.01)$ & & 110 & $6.11(0.02)$ \\
\hline & & $\left(\mathrm{pk}^{\mathrm{H}}=3.65\right)$ & & 111 & $7.76(0.05)$ \\
\hline
\end{tabular}

Glycylglycine

Succinic acid

$\begin{array}{lll}0 & 11 & 7.77(0.01) \\ 012 & 10.81(0.01) \\ 110 & 7.71(0.01) \\ 11-1 & 2.61(0.08)\end{array}$

$\begin{array}{lll}0 & 11 & 5.24(0.02) \\ 0 & 12 & 9.17(0.03) \\ 11 & 0 & 4.21(0.00) \\ 111 & 9.16(0.01)\end{array}$

Aspargine

$\begin{array}{cc}011 & 8.35(0.01) \\ 012 & 10.51(0.03) \\ 110 & 9.30(0.02) \\ 11-1 & -0.50(0.04) \\ & \left(\mathrm{pk}^{\mathrm{H}}=9.80\right)\end{array}$

Malonic acid

$\begin{array}{lll}011 & 5.01(0.02) \\ 012 & 7.65(0.03) \\ 110 & 5.68(0.02) \\ 111 & 8.15(0.06)\end{array}$

Glycylleucine

$\begin{array}{cc}011 & 7.91(0.01) \\ 110 & 7.35(0.03) \\ 11-1 & 1.98(0.08) \\ & \left(\mathrm{pk}^{\mathrm{H}}=5.37\right)\end{array}$

Adipic Acid

$\begin{array}{lll}011 & 5.25(0.03) \\ 012 & 9.14(0.04) \\ 110 & 3.98(0.00) \\ 111 & 8.26(0.00)\end{array}$

Glutamine

$\begin{array}{cc}011 & 8.77(0.01) \\ 012 & 10.78(0.02) \\ 110 & 9.40(0.02) \\ 11-1 & -1.40(0.05) \\ & \left(\mathrm{pk}^{\mathrm{H}}=10.80\right)\end{array}$

Oxalic acid

$\begin{array}{lll}011 & 3.76(0.02) \\ 012 & 5.37(0.03) \\ 110 & 5.84(0.07) \\ 111 & 8.06(0.07)\end{array}$

Inosine

$\begin{array}{ll}011 & 8.43(0.02) \\ 110 & 7.38(0.03) \\ 120 & 10.64(0.05) \\ 111 & 11.89(0.05)\end{array}$

Fumaric acid

\begin{tabular}{lll}
011 & $4.27(0.04)$ \\
012 & $6.63(0.04)$ \\
110 & $4.23(0.04)$ \\
111 & $7.74(0.06)$ \\
\hline
\end{tabular}


TABle 2: Continued.

\begin{tabular}{|c|c|c|c|c|c|}
\hline Ligand & $\mathrm{MLH}^{\mathrm{a}}$ & $\log \beta^{\mathrm{b}}$ & Ligand & $\mathrm{MLH}^{\mathrm{a}}$ & $\log \beta^{\mathrm{b}}$ \\
\hline \multirow[t]{6}{*}{ Inosine- $5^{\prime}$-monophosphate } & & & Cytidine- $5^{\prime}$-monophosphate & & \\
\hline & 011 & $8.83(0.02)$ & & 011 & $6.12(0.02)$ \\
\hline & 012 & $15.07(0.03)$ & & 012 & $10.42(0.03)$ \\
\hline & 110 & $8.18(0.03)$ & & 110 & $5.59(0.07)$ \\
\hline & 120 & $13.35(0.04)$ & & 120 & $8.37(0.09)$ \\
\hline & 111 & $13.93(0.04)$ & & 111 & $10.66(0.05)$ \\
\hline \multirow[t]{6}{*}{ Adenine } & & & Uridine- $5^{\prime}$-monophosphate & & \\
\hline & 011 & $9.29(0.03)$ & & 011 & $9.23(0.01)$ \\
\hline & 012 & $13.32(0.04)$ & & 012 & $15.12(0.02)$ \\
\hline & 110 & $9.17(0.11)$ & & 110 & $9.14(0.01)$ \\
\hline & 120 & $13.77(0.02)$ & & 120 & $13.82(0.02)$ \\
\hline & 111 & $18.36(0.02)$ & & 111 & $15.15(0.04)$ \\
\hline \multirow[t]{4}{*}{ Cytosine } & & & Uracil & & \\
\hline & 011 & $4.45(0.02)$ & & 011 & $8.98(0.01)$ \\
\hline & 110 & $5.68(0.03)$ & & 110 & $8.33(0.04)$ \\
\hline & 120 & $8.51(0.04)$ & & 120 & $13.70(0.08)$ \\
\hline \multirow[t]{6}{*}{ Guanosine } & & & Guanosine- $5^{\prime}$-monophosphate & & \\
\hline & 011 & $8.91(0.01)$ & & 011 & $9.18(0.02)$ \\
\hline & 012 & $11.01(0.02)$ & & 012 & $15.12(0.03)$ \\
\hline & 110 & $10.18(0.06)$ & & 110 & $9.03(0.06)$ \\
\hline & 120 & $18.88(0.06)$ & & 120 & $13.44(0.19)$ \\
\hline & & & & 111 & $15.06(0.01)$ \\
\hline \multirow[t]{4}{*}{ Adenosine } & & & Thymidine & & \\
\hline & 011 & $3.40(0.01)$ & & 011 & $9.28(0.04)$ \\
\hline & 110 & $2.74(0.04)$ & & 110 & $8.05(0.08)$ \\
\hline & 120 & $5.15(0.00)$ & & 120 & $13.22(0.04)$ \\
\hline
\end{tabular}

${ }^{a} \mathrm{M}, \mathrm{L}$ and $\mathrm{H}$ are the stoichiometric coefficients corresponding to $\mathrm{Pd}(\mathrm{DEEN})$, ligands, and $\mathrm{H}^{+}$, respectively; the coefficient -1 refers to a proton loss.

${ }^{\mathrm{b}} \log \beta$ of Pd(DEEN)- ligands. Standard deviations are given in parentheses; sum of square of residuals are less than $5 e^{-7}, \mathrm{pK}^{\mathrm{H}}=\log \beta_{110}-\log \beta_{11-1}$.

where $\mathrm{M}, \mathrm{L}$, and $\mathrm{H}$ stand for $\left[\mathrm{Pd}(\mathrm{DEEN})\left(\mathrm{H}_{2} \mathrm{O}\right)_{2}\right]^{2+}$ ion, ligand, and proton, respectively. The calculations were performed using the computer program [14] MINIQUAD75 . The stoichiometry and stability constants of the complexes formed were determined by trying various possible composition models for the systems studied. The model selected was that which gave the best statistical fit and was chemically consistent with the magnitudes of various residuals, as described elsewhere [14]. Tables 1 and 2 list the stability constants together with their standard deviations and the sum of the squares of the residuals derived from the MINIQUAD output. The concentration distribution diagrams were obtained with the program SPECIES [15] under the experimental condition used.

The hydrolysis kinetics of the complex ester was monitored by $\mathrm{pH}$-stat technique, $[13,16,17]$ by using the titroprocessor operating in the SET mode. The hydrolysis was investigated using an aqueous solution $(40 \mathrm{~mL})$ containing a mixture of $\left[\mathrm{Pd}(\text { DEEN })\left(\mathrm{H}_{2} \mathrm{O}\right)_{2}\right]^{2+}(1 \mathrm{mmol})$ and Smethylcysteine methyl ester $(1 \mathrm{mmol})$, and the ionic strength was adjusted to $0.16 \mathrm{M}$ with $\mathrm{NaNO}_{3}$. The $\mathrm{pH}$ of the mixture was progressively raised to the desired value. The reaction was monitored by addition of $\mathrm{NaOH}$ solution to maintain
TABLE 3: Kinetic data for hydrolysis of [Pd(DEEN)(cysteine methyl ester) $]^{2+}$ at $25^{\circ} \mathrm{C}$ and $0.1 \mathrm{M}$ ionic strength.

\begin{tabular}{lcc}
\hline $\mathrm{pH}$ & {$\left[\mathrm{OH}^{-}\right] / \mathrm{M}$} & $\mathrm{k}_{\mathrm{obs}} / \mathrm{s}^{-1}$ \\
\hline 8.8 & $7.59 \mathrm{E}-06$ & $4.95 \mathrm{E}-04$ \\
9.0 & $1.20 \mathrm{E}-05$ & $7.67 \mathrm{E}-04$ \\
9.2 & $1.91 \mathrm{E}-05$ & $1.39 \mathrm{E}-03$ \\
9.4 & $3.02 \mathrm{E}-05$ & $1.88 \mathrm{E}-03$ \\
9.6 & $4.79 \mathrm{E}-05$ & $3.36 \mathrm{E}-03$ \\
\hline
\end{tabular}

TABLE 4: Kinetic data for the hydrolysis of [Pd(DEEN)(cysteine methyl ester) $]^{2+}$ at $25^{\circ} \mathrm{C}$ and $0.1 \mathrm{M}$ ionic strength.

\begin{tabular}{lccc}
\hline $\mathrm{k}_{\mathrm{OH}}$ & $\mathrm{k}_{\mathrm{o}}$ & $\mathrm{k}_{\mathrm{OH}^{(\text {ester) }}}$ & $\mathrm{k}_{\mathrm{OH}} / \mathrm{k}_{\mathrm{OH}}$ (ester) \\
\hline $\mathrm{M}^{-1} \mathrm{~s}^{-1}$ & $\mathrm{~s}^{-1}$ & $\mathrm{M}^{-1} \mathrm{~s}^{-1}$ & \\
\hline $6.98 \mathrm{E}+01$ & $9.270 \mathrm{E}-07$ & 0.767 & $9.10 \mathrm{E}+01$ \\
\hline
\end{tabular}

${ }^{\mathrm{a}}$ Data taken from $[16,17]$

the given $\mathrm{pH}$. The data fitting was performed with the OLIS KINFIT set of programs [18] as described previously $[19,20]$. 


\section{Results and Discussion}

The acid dissociation constants of the ligands were determined under the experimental conditions $37^{\circ} \mathrm{C}$ and constant $0.16 \mathrm{M}$ ionic strength (adjusted with $\mathrm{NaNO}_{3}$ ), which were also used for determining the stability constants of the $\operatorname{Pd}(\mathrm{II})$ complexes.

3.1. The Hydrolysis of $\left[\mathrm{Pd}(\mathrm{DEEN}) \quad\left(\mathrm{H}_{2} \mathrm{O}\right)_{2}\right]^{2+}$. The $\left[\mathrm{Pd}(\mathrm{DEEN})\left(\mathrm{H}_{2} \mathrm{O}\right)_{2}\right]^{2+}$ ion may undergo hydrolysis. Its acid-base chemistry was characterized by fitting the potentiometric data to various acid-base models. The best-fit model was found to be consistent with the formation of three species: $10-1,10-2$, and $20-2$, as given in reactions (3)-(5). Trials were made to fit the potentiometric data assuming the formation of the monohydroxo-bridged dimer, 20-1, but this resulted in a very poor fit to the data. The dimeric species 20-2 was detected by Nagy and Sóvágó [21], for a similar system:

$$
\begin{aligned}
& \underset{100}{\left[\mathrm{Pd}(\mathrm{DEEN})\left(\mathrm{H}_{2} \mathrm{O}\right)_{2}\right]^{2+}} \\
& \stackrel{\mathrm{K}_{\mathrm{al}}}{=}\left[\mathrm{Pd}(\mathrm{DEEN})\left(\mathrm{H}_{20-1} \mathrm{O}\right)(\mathrm{OH})\right]^{+}+\mathrm{H}^{+},
\end{aligned}
$$

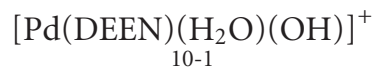



$$
\begin{aligned}
& 2\left[\mathrm{Pd}(\mathrm{DEEN}) \underset{10-1}{\left.\left(\mathrm{H}_{2} \mathrm{O}\right)(\mathrm{OH})\right]^{+}}\right. \\
& \stackrel{\mathrm{K}_{\text {dimer }}}{=}\left[\mathrm{Pd}(\mathrm{DEEN})\left(\underset{20-2}{(\mathrm{OH})_{2}} \mathrm{Pd}(\mathrm{DEEN})\right]^{2+}\right. \text {. }
\end{aligned}
$$

The $\mathrm{pK}_{\mathrm{a} 1}$ and $\mathrm{pK}_{\mathrm{a} 2}$ values for $\left[\mathrm{Pd}(\mathrm{DEEN})\left(\mathrm{H}_{2} \mathrm{O}\right)_{2}\right]^{2+}$ are 5.11 and 9.69, respectively, The equilibrium constant for the dimerization reaction (5) can be calculated by (6) and amounts to 3.02:

$$
\log \mathrm{K}_{\text {dimer }}=\log \beta_{20-2}-2 \log \beta_{10-1} .
$$

The distribution diagram for $\left[\mathrm{Pd}(\mathrm{DEEN})\left(\mathrm{H}_{2} \mathrm{O}\right)_{2}\right]^{2+}$ and its hydrolyzed species is given in Figure 1 and reveals that the concentration of the monohydroxo species 10-1, and the dimeric species 20-2 increase with increasing $\mathrm{pH}$, predominate in the $\mathrm{pH}$ range $6-8$, and reach a maximum concentration of $\sim 50 \%$. A further increase in $\mathrm{pH}$ is accompanied by an increase in the dihydroxo species (10-2), which is the main species above $\mathrm{pH} \sim 10.0$. This reveals that, in the physiological $\mathrm{pH}$ range, that is, at $\mathrm{pH}$ 6-7, the monohydroxo complex (10-1) predominates and can interact with the DNA subunits. At higher $\mathrm{pH}$ the inert dihydroxo complex will be the major species, and consequently the ability of DNA to bind the $\mathrm{Pd}($ amine) complex will decrease significantly.

3.2. Amino Acid Complexes. Analysis of the titration data for the $\mathrm{Pd}(\mathrm{DEEN})$-amino acid system showed the formation of $1: 1$ species. Histidine, ornithine, lysine, glutamic acid,

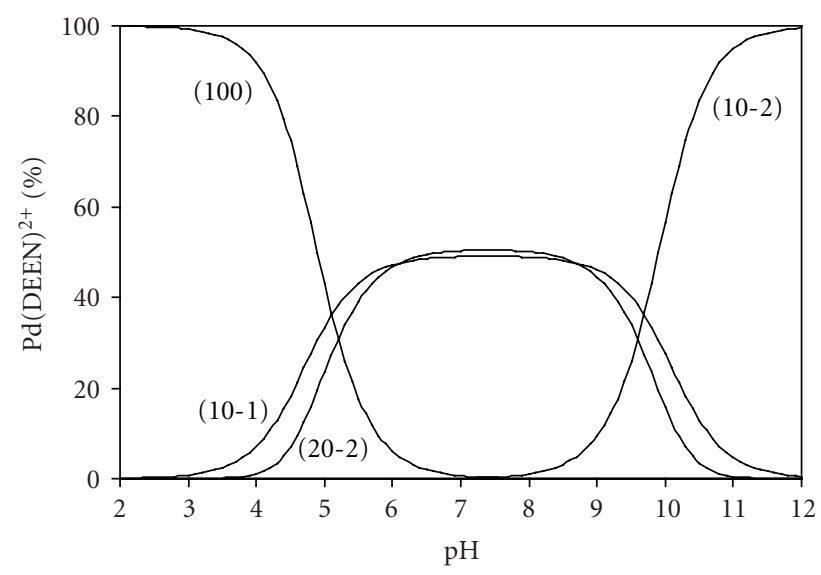

FIgURE 1: Concentration distribution diagram for the hydrolysis of $\left[\mathrm{Pd}(\mathrm{DEEN})\left(\mathrm{H}_{2} \mathrm{O}\right)_{2}\right]^{2+}$.

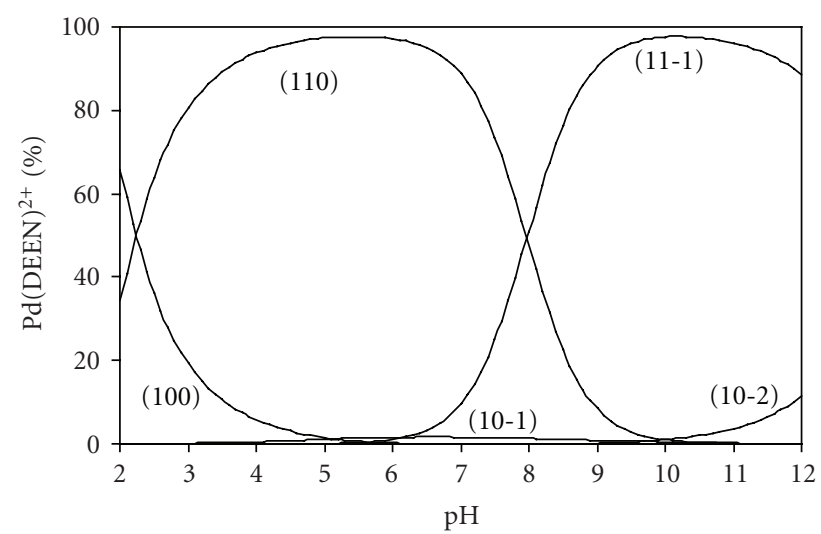

FIGURE 2: Concentration distribution diagram for various complex species in $\mathrm{Pd}(\mathrm{DEEN})^{2+}$-serine system.

aspartic acid, and cysteine form, in addition to $1: 1$ complexes, the monoprotonated species. The $\mathrm{pk}_{\mathrm{a}}$ of the protonated complex was calculated from (7):

$$
\mathrm{pk}_{\mathrm{a}}=\log \beta_{111}-\log \beta_{110}
$$

The $\mathrm{pk}_{\mathrm{a}}$ values of the protonated species are 2.95 for histidine, 7.20 for ornithine, 8.58 for lysine, 3.17 for glutamic acid and, 3.39 for aspartic acid. The stability constants of the histidine, ornithine, and lysine complexes are higher than those of simple amino acids. This indicates that these amino acids coordinate via the two nitrogen centres, that is, imidazole and amino groups in the case of histidine, and by two amino groups in the case of ornithine and lysine. This is in line with the strong affinity of $\mathrm{Pd}(\mathrm{II})$ for nitrogen donor centres. Aspartic acid and glutamic acid have two carboxylic and one amino groups as potential binding centres. They may coordinate either via the two carboxylate groups or by the amino group and one carboxylate group. The stability constants of their complexes are in the range of those of amino acids. This may reveal that aspartic acid and glutamic 




Figure 3: Concentration distribution diagram for various complex species in $\mathrm{Pd}(\mathrm{DEEN})^{2+}$-glycylglycine system.

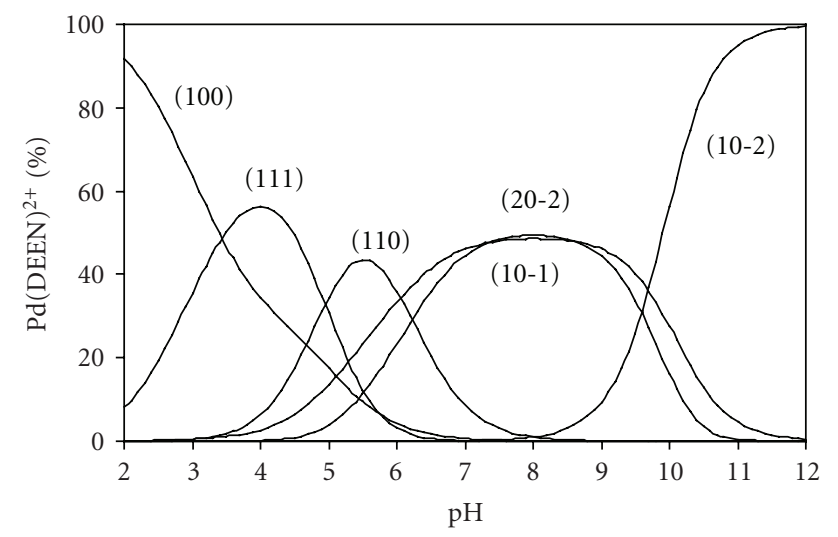

Figure 4: Concentration distribution diagram for various complex species in $\mathrm{Pd}(\mathrm{DEEN})^{2+}$-succinic acid System.

acid coordinate via the amino and one carboxylate groups. Serine and threonine have an extra binding centre on the $\beta$ alcoholate group. This group was reported [22] to participate in metal complex formation. The potentiometric data is much better fitted assuming the formation of the complex species 110 and 11-1. This reveals that the $\beta$-alcoholate group participates in complex formation through induced ionization of the alcoholic group forming the species 111. The $\mathrm{pk}^{\mathrm{H}}$ value of the $\beta$-alcoholate incorporated in the $\mathrm{Pd}(\mathrm{II})$ complex $\left(\log \beta_{110}-\log \beta_{11-1}\right)$ is 7.97 and 7.88 for serine and threonine, respectively. Also, ethanolamine forms the complex species 110,120 , and $11-1$, and the $\log \beta_{110}$ value for ethanolamine complex is smaller than that for amino acids. This may be due to the coordination of ethanolamine at low $\mathrm{pH}$ occurring through the amino and neutral alcohol groups, while in the case of serine and threonine the coordination is through amino and carboxylate groups. At high $\mathrm{pH}$, the hydroxyl group is coordinated and undergoes induced ionization forming the species $11-1$. The $\mathrm{pk}^{\mathrm{H}}$ value of the coordinated alcohol group in ethanolamine (4.98) is smaller than that of serine and threonine. This is consistent with the reaction scheme where the alcohol group in ethanolamine is coordinated with the $\operatorname{Pd}(\mathrm{DEEN})^{2+}$, while the alcohol group in serine and threonine is competing with the carboxylate group in binding to $\operatorname{Pd}(\mathrm{DEEN})^{2+}$ ion. Due to coordination of the alcohol group by donation of the electron pair on the oxygen to the metal centre, the $\mathrm{OH}$ bond is considerably weakened, and thus the ionization of a proton occurs at a lower $\mathrm{pH}$.

The distribution diagram for the serine complex, given in Figure 2, shows that the complex species with coefficients 110 reaches the maximum degree of formation $(\sim 97 \%)$ at $\mathrm{pH} 5.0$ to 6.0 , that is, in the physiological $\mathrm{pH}$ range. However, the species 11-1 predominates after $\mathrm{pH} 8.5$ and attains the maximum concentration of $\sim 98 \%$ at $\mathrm{pH} \sim 9.5$.

3.3. Peptide Complexes. The potentiometric data for the peptide complexes were fitted on the basis of formation of the complexes with stoichiometric coefficients 110 and 11-1 according to the following equilibria, where $\mathrm{HL}$ is peptide:

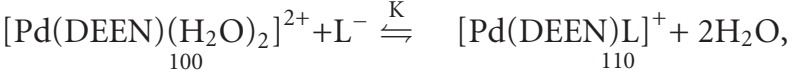

$$
\begin{aligned}
& {[\operatorname{Pd}(\mathrm{DEEN}) \mathrm{L}]^{+} \stackrel{\mathrm{K}^{\mathrm{H}}}{=}\left[\underset{110}{\operatorname{Pd}(\mathrm{DEEN}) \mathrm{LH}_{-1}}\right]+\mathrm{H}^{+} .}
\end{aligned}
$$

The 110 complex is formed via coordination of the amine and carbonyl groups. On increasing the $\mathrm{pH}$, the coordination site should switch from the carbonyl oxygen to the amide nitrogen with release of the amide hydrogen forming the complex $\left[\mathrm{Pd}(\mathrm{DEEN})\left(\mathrm{LH}_{-1}\right)\right]$. Such changes in coordination centres are now well documented [23]. The $\mathrm{pK}^{\mathrm{H}}$ values of the amide groups incorporated in the $\mathrm{Pd}(\mathrm{II})$ complexes $\left(\log \beta_{110}-\log \beta_{11-1}\right)$ are in the 3.65-10.80 range. It is noteworthy that the $\mathrm{pK}^{\mathrm{H}}$ for glycinamide complex is lower than that of other peptides. This signifies that the more bulky substituent group on the peptide may serve to hinder the structural change in going from the protonated to the deprotonated complexes. The $\mathrm{pK}^{\mathrm{H}}$ of the glutamine complex is markedly higher than that for other peptide complexes. This is ascribed to the formation of a seven-membered chelate ring, which would probably be more strained and therefore less favoured.

The relative magnitude of the $\mathrm{pK}^{\mathrm{H}}$ values of the $\mathrm{Pd}(\mathrm{II})$ complexes with peptides has interesting biological implications. Under normal physiological conditions ( $\mathrm{pH}$ 6-7) the peptide would coordinate to $\left[\mathrm{Pd}(\mathrm{DEEN})\left(\mathrm{H}_{2} \mathrm{O}\right)_{2}\right]^{2+}$ in entirely different fashions. Glutaminate would exist solely in the protonated form, whereas the other peptides would be present entirely in the deprotonated form. In addition, the slight difference in the side chain of the peptides produces dramatic differences in their behaviour towards the palladium species. The speciation diagram of glycylglycine complex is given in Figure 3. The $\operatorname{Pd}(\mathrm{DEEN})(\mathrm{L})^{+}(110)$ species starts to form at $\mathrm{pH} 2.0$ and with increasing of $\mathrm{pH}$, its concentration increases reaching the maximum of $70 \%$ at $\mathrm{pH}$ 4.3. Further increase of $\mathrm{pH}$ is accompanied by a decrease in $\operatorname{Pd}(\mathrm{DEEN})(\mathrm{L})^{+}$complex concentration and an increase of $\operatorname{Pd}(\mathrm{DEEN})\left(\mathrm{LH}_{-1}\right)$ complex formation. 


$$
\begin{gathered}
{\left[\mathrm{Pd}(\mathrm{DEEN})\left(\mathrm{H}_{2} \mathrm{O}\right)_{2}\right]^{2+}+\mathrm{NH}_{2} \mathrm{CH}(\mathrm{R}) \mathrm{COOR}^{\prime} \stackrel{\mathrm{K}_{f}}{=}\left[\mathrm{Pd}(\mathrm{DEEN})\left(\mathrm{NH}_{2} \mathrm{CH}(\mathrm{R}) \mathrm{COOR}^{\prime}\right)\right]^{2+}+2 \mathrm{H}_{2} \mathrm{O}} \\
\mathrm{OH}^{-} \downarrow \mathrm{K}_{\mathrm{OH}} \\
{\left[\mathrm{Pd}(\mathrm{DEEN})\left(\mathrm{NH}_{2} \mathrm{CH}(\mathrm{R}) \mathrm{COO}\right)\right]^{+}+\mathrm{R}^{\prime} \mathrm{OH}}
\end{gathered}
$$

Scheme 1

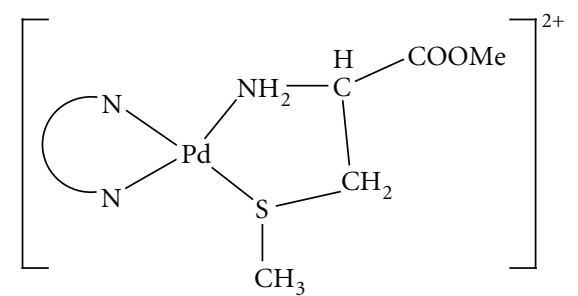

SCHEMe 2

3.4. Dicarboxylic Acid Complexes. In the Pd(DEEN)dicarboxylic acid system, the results showed the presence of the 1: 1 species and its protonated form. The results in Table 2 show that the adipic acid complex is the least stable as the complex involves the formation of the least stable eight-membered chelate ring. The $\mathrm{pK}_{\mathrm{a}}$ values of the protonated species for $[\mathrm{Pd}(\mathrm{DEEN}) \mathrm{HL}]^{+}$are in the range 1.65 - 4.95. These values are lower than those for the $\mathrm{HL}^{-}$ion see Table 2. The lowering of the $\mathrm{pK}_{\mathrm{a}}$ is due to acidification of the second carboxylic acid group upon coordination of $\mathrm{Pd}(\mathrm{II})$ to one carboxylate group [24].

From the concentration distribution diagram of the succinic acid complex, given in Figure 4, it is interesting to note that the monoprotonated species attains its maximum concentration of $58 \%$ at $\mathrm{pH} 3.8$. This form has one coordination site available for binding to DNA. Such species was documented to be the active form in the case of carboplatin [25].

3.5. DNA Complexes. DNA constituents, such as adenosine, cytosine, uracil, and thymidine, form $1: 1$ and $1: 2$ complexes with the $\operatorname{Pd}(\mathrm{DEEN})^{2+}$ ion. However, inosine, adenine and nucleotides such as inosine- $5^{\prime}$-monophosphate, guanosine $-5^{\prime}$-monophosphate, cytidine $-5^{\prime}$-monophosphate and uridine- $5^{\prime}$-monophosphate, form the monoprotonated complex, in addition to the formation of $1: 1$ and $1: 2$ complexes. The $\mathrm{pK}_{\mathrm{a}}$ value of the protonated inosine complex is 4.51. This value corresponds to $\mathrm{N}_{1} \mathrm{H}$. The lowering of this value with respect to that of free inosine $\left(\mathrm{pK}_{\mathrm{a}}=8.43\right)$ is due to acidification upon complex formation [26]. The $\mathrm{pK}_{\mathrm{a}}$ values of the protonated nucleotide complexes are 5.75, 6.03, 5.07, and 6.01 for inosine $-5^{\prime}$-monophosphate, guanosine- $5^{\prime}$ monophosphate, cytidine $-5^{\prime}$-monophosphate, and uridine$5^{\prime}$-monophosphate respectively.

The pyrimidines uracil, uridine- $5^{\prime}$-monophosphate, thymidine-5'-monophosphate, and thymidine have basic nitrogen donor atoms $\left(\mathrm{N}_{3}\right)^{26}$ as a result of the high $\mathrm{pK}_{\mathrm{a}}$ values of pyrimidines $\left(\mathrm{pK}_{\mathrm{a}}>9\right)$, and the complexes formed predominates above $\mathrm{pH}$ 8.5. Both cytosine and cytidine$5^{\prime}$-monophosphate undergo $\mathrm{N}_{3}^{27}$ protonation under mild acidic conditions. The values obtained for their protonation constants are 4.45 and 6.12, respectively. The lower values of the stability constants of their complexes, Table 2 , reflect the difference in the basicity of the donor site.

It was shown above that $\mathrm{N}$-donor ligands such as DNA constituents have affinity for $\left[\mathrm{Pd}(\mathrm{DEEN})\left(\mathrm{H}_{2} \mathrm{O}\right)_{2}\right]^{2+}$, which may have important biological implications since the interaction with DNA is thought to be responsible for the antitumour activity of related complexes. However, the preference of $\mathrm{Pd}(\mathrm{II})$ to coordinate to S-donor ligands was demonstrated as shown in Tables 1 and 2. These results suggest that $\mathrm{Pd}(\mathrm{II})-\mathrm{N}$ adducts can easily be converted into Pd-S adducts [27]. Consequently, the equilibrium constant for such conversion is of biological significance. Consider inosine as a typical DNA constituent (presented by HA) and cysteine as a typical thiol ligand (presented by $\mathrm{H}_{2} \mathrm{~B}$ ). The equilibria involved in complex-formation and displacement reactions are

$$
\begin{gathered}
\mathrm{HA} \rightleftharpoons \mathrm{H}^{+}+\mathrm{A}^{-}, \\
\mathrm{H}_{2} \mathrm{~B} \rightleftharpoons 2 \mathrm{H}^{+}+\mathrm{B}^{2-}, \\
{\left[\mathrm{Pd}(\mathrm{DEEN})\left(\mathrm{H}_{2} \mathrm{O}\right)_{2}\right]^{2+}+\mathrm{A}^{-} \rightleftharpoons[\mathrm{Pd}(\mathrm{DEEN}) \mathrm{A}]^{+}+2 \mathrm{H}_{2} \mathrm{O}} \\
(100) \\
\beta_{110}^{[\mathrm{Pd}(\mathrm{DEEN}) \mathrm{A}]+}=\frac{\left[\mathrm{Pd}(\mathrm{DEEN}) \mathrm{A}^{+}\right]}{\left[\mathrm{Pd}(\mathrm{DEEN})\left(\mathrm{H}_{2} \mathrm{O}\right)_{2}\right]^{2+}\left[\mathrm{A}^{-}\right]}, \\
{\left[\mathrm{Pd}(\mathrm{DEEN})\left(\mathrm{H}_{2} \mathrm{O}\right)_{2}\right]^{2+}+\mathrm{B}^{2-} \rightleftharpoons[\mathrm{Pd}(\mathrm{DEEN}) \mathrm{B}]+2 \mathrm{H}_{2} \mathrm{O}} \\
100 \\
\beta_{110}^{[\mathrm{Pd}(\mathrm{DEEN}) \mathrm{B}]}=\frac{[\mathrm{Pd}(\mathrm{DEEN}) \mathrm{B}]}{\left[\mathrm{Pd}(\mathrm{DEEN})\left(\mathrm{H}_{2} \mathrm{O}\right)_{2}\right]^{2+}\left[\mathrm{B}^{2-}\right]} \\
{[\mathrm{Pd}(\mathrm{DEEN})(\mathrm{A})]^{+}+\mathrm{B}^{2-} \stackrel{\mathrm{K}_{\text {eq }}}{=}[\mathrm{Pd}(\mathrm{DEEN})(\mathrm{B})]+\mathrm{A}^{-}}
\end{gathered}
$$

The equilibrium constant for the displacement reaction given in (13) is given by

$$
\mathrm{K}_{\mathrm{eq}}=\frac{[\operatorname{Pd}(\mathrm{DEEN})(\mathrm{B})]\left[\mathrm{A}^{-}\right]}{\left[\operatorname{Pd}(\mathrm{DEEN})(\mathrm{A})^{+}\right]\left[\mathrm{B}^{2-}\right]} .
$$


Substitution from (10) and (12) in (14) results in:

$$
\mathrm{K}_{\mathrm{eq}}=\frac{\beta_{110}^{[\mathrm{Pd}(\mathrm{DEEN}) \mathrm{B}]}}{\beta_{110}^{[\mathrm{Pd}(\mathrm{DEEN}) \mathrm{A}]^{+}}}
$$

where $\log \beta_{110}$ values for $[\operatorname{Pd}(\operatorname{DEEN})(\mathrm{A})]^{+}$and $[\mathrm{Pd}(\mathrm{DEEN}) \mathrm{B}]$ complexes taken from Table 2 amount to 7.38 and 14.11, respectively, and by substitution in (15) results in $\log \mathrm{K}_{\text {eq }}=6.73$. In the same way the equilibrium constants for the displacement of coordinated inosine by glycine and methionine are $\log \mathrm{K}_{\mathrm{eq}}=2.95$ and 1.94, respectively. These values clearly indicate how sulfhydryl ligands such as cysteine and, by analogy, glutathione are effective in displacing the DNA constituent, that is, the main target in tumour chemotherapy. Chelated cyclobutanedicarboxylate may undergo displacement reaction with inosine. $\log \mathrm{K}_{\mathrm{eq}}$ for such a reaction was calculated as described above and amounts to 1.27. The low value of the equilibrium constant for the displacement reaction of coordinated cyclobutanedicarboxylate by inosine is of biological significance since it is in line with the finding that carboplatin interacts with DNA through ring opening of chelated CBDCA and not through displacement of CBDCA.

3.6. Kinetics of Hydrolysis of Amino Acid Esters. The hydrolysis of amino acid esters can be presented as shown in Scheme 1.

The equilibrium constant for S-methylcysteine methyl ester $\left(\mathrm{K}_{\mathrm{f}}\right)$ is sufficiently large that coordination of the ester is readily accomplished. The kinetic data, name, the volume of base added to keep the $\mathrm{pH}$ constant versus time, could be fitted by a single exponential function. A plot of $k_{o b s}$ versus hydroxide ion concentration is linear and follows the rate expression $\mathrm{k}_{\mathrm{obs}}=\mathrm{k}_{\mathrm{o}}+\mathrm{k}_{\mathrm{OH}}\left[\mathrm{OH}^{-}\right]$, where $\mathrm{k}_{\mathrm{o}}$ represents the rate constant for the water-catalyzed pathway and $\mathrm{k}_{\mathrm{OH}}$ the rate constant for the base-catalyzed pathway, the kinetic data are given in Table 3. The linear dependence of the rate constant on the $\mathrm{OH}^{-}$concentration is consistent with direct attack of $\mathrm{OH}^{-}$ion on the ester carbonyl group. The catalysis ratio $\mathrm{C}=\mathrm{k}_{\mathrm{OH}} / \mathrm{k}_{\mathrm{OH}^{\text {ester }}}$, where $\mathrm{k}_{\mathrm{OH}^{\text {ester }}}$ represents the rate constant for the hydrolysis of the free amino acid ester, is given in Table 4 . The catalysis ratio for coordinated cysteine methyl ester equals 91.0. A catalysis ratio of such low value is consistent with the structural formula for the mixed-ligand complex, in which there is no direct interaction between the $\mathrm{Pd}^{\mathrm{II}}$ ion and the ester carbonyl group. The relatively low catalysis ratio is probably due to activation by induction through the coordinated nitrogen atom as reported previously $[28,29]$.

\section{Acknowledgement}

The author in indebted to the Department of Chemistry, Faculty of Science, Taif University, Saudi Arabia, for the financial support for the present project.

\section{References}

[1] B. Lippert, Ed., Chemistry and Biochemistry of Leading Anticancer Drugs, Wiley-VCH, Weinheim, Germany, 1999.

[2] I. H. Krakoff, in Platinum and Other Metal Coordination Compounds in Cancer Chemotherapy: Clinical Applications of Platinum Complexes, M. Nicolini, Ed., p. 351, Martinus Nijhoff, Boston, Mass, USA, 1988.

[3] E. Wong and C. M. Giandornenico, "Current status of platinum-based antitumor drugs," Chemical Reviews, vol. 99, no. 9, pp. 2451-2466, 1999.

[4] M. R. Shehata, M. M. Shoukry, F. M. Nasr, and R. van Eldik, "Complex-formation reactions of dicholoro(S-methylL-cysteine)palladium(II) with bio-relevant ligands. Labilization induced by S-donor chelates," Dalton Transactions, no. 6, pp. 779-786, 2008.

[5] A. A. El-Sherif and M. M. Shoukry, "Ternary copper(II) complexes involving 2-(aminomethyl)-benzimidazole and some bio-relevant ligands. Equilibrium studies and kinetics of hydrolysis for glycine methyl ester under complex formation," Inorganica Chimica Acta, vol. 360, no. 2, pp. 473-487, 2007.

[6] A. A. El-Sherif and M. M. Shoukry, "Equilibrium investigation of complex formation reactions involving copper(II), nitrilotris(methyl phosphonic acid) and amino acids, peptides or DNA constitutents. The kinetics, mechanism and correlation of rates with complex stability for metal ion promoted hydrolysis of glycine methyl ester," Journal of Coordination Chemistry, vol. 59, no. 14, pp. 1541-1556, 2006.

[7] A. A. Al-Najjar, M. M. A. Mohamed, and M. M. Shoukry, "Interaction of dipropyltin(IV) with amino acids, peptides, dicarboxylic acids and DNA constituents," Journal of Coordination Chemistry, vol. 59, no. 2, pp. 193-206, 2006.

[8] M. M. Shoukry and E. M. Shoukry, Collection of Czechoslovak Chemical Communications, vol. 58, p. 1103, 1993.

[9] E. M. Shoukry, International Journal for Chemistry, vol. 3, no. 4, p. 193, 1992.

[10] M. R. Shehata, M. M. Shoukry, F. M. Nasr, and R. van Eldik, "Complex-formation reactions of dicholoro(S-methylL-cysteine)palladium(II) with bio-relevant ligands. Labilization induced by S-donor chelates," Journal of the Chemical Society, Dalton Transactions, no. 6, pp. 779-786, 2008.

[11] Ž. D. Bugarčič, M. M. Shoukry, and R. van Eldik, "Equilibrium and kinetic data for the interaction of diaqua-(S-methylL-cysteine)palladium(II) with biologically relevant ligands," Journal of the Chemical Society, Dalton Transactions, no. 21, pp. 3945-3951, 2002.

[12] R. G. Bates, Determination of pH: Theory and Practice, Wiley Interscience, New York, NY, USA, 2nd edition, 1975.

[13] M. M. Shoukry, W. M. Hosny, and M. M. Khalil, "Equilibrium and hydrolysis of $\alpha$-amino acid esters in mixed-ligand complexes with $N$-(acetamido)-iminodiacetatecopper(II)," Transition Metal Chemistry, vol. 20, no. 3, pp. 252-255, 1995.

[14] P. Gans, A. Sabatini, and A. Vacca, "An improved computer program for the computation of formation constants from potentiometric data," Inorganica Chimica Acta, vol. 18, pp. 237-239, 1976.

[15] L. Pettit, personal communication, University of Leeds, 1993.

[16] R. W. Hay and C. You-Quan, "The copper(II)-2,2'dipyridylamine promoted hydrolysis of glycine ethyl ester. Kinetic evidence for intramolecular attack by coordinated hydroxide," Polyhedron, vol. 14, no. 7, pp. 869-872, 1995.

[17] R. W. Hay and P. J. Morris, in Metal Ions in Biological Systems, H. Sigel, Ed., vol. 5, p. 173, Marcel Dekker, New York, NY, USA, 1976. 
[18] OLIS KINFIT, Olis Inc., Borgart, Ga, USA, 1993.

[19] M. Shoukry and R. van Eldik, "Correlation between kinetic and thermodynamic complex-formation constants for the interaction of bis(amine)palladium(II) with inosine, inosine $5^{\prime}$-monophosphate and guanosine $5^{\prime}$-monophosphate," Journal of the Chemical Society, Dalton Transactions, no. 13, pp. 2673-2678, 1996.

[20] O. Al-Flaijj, M. R. Shehata, M. M. A. Mohamed, and M. M. Shoukry, "Interaction of dimethyltin(IV) with DNA constituents," Monatshefte für Chemie, vol. 132, no. 3, pp. 349366, 2001.

[21] Z. Nagy and I. Sóvágó, "Thermodynamic and structural characterisation of the complexes formed in the reaction of $\left[\mathrm{Pd}(\mathrm{en})\left(\mathrm{H}_{2} \mathrm{O}\right)_{2}\right]^{2+}$ and $\left[\mathrm{Pd}(\mathrm{pic})\left(\mathrm{H}_{2} \mathrm{O}_{2}\right)\right]^{2+}$ with $\mathrm{N}$-alkyl nucleobases and $\mathrm{N}$-acetyl amino acids," Journal of the Chemical Society, Dalton Transactions, no. 17, pp. 2467-2475, 2001.

[22] M.-C. Lim, "Mixed-ligand complexes of palladium. 5. Diaqua(ethylenediamine)palladium(II) complexes of ethanolamine, L-serine, L-threonine, L-homoserine, and L-hydroxyproline," Inorganic Chemistry, vol. 20, no. 5, pp. 1377-1379, 1981.

[23] M. C. Lim, "Mixed-ligand complexes of palladium(II) part 1: diaqua(ethylenediamine) palladium(II) complexes of glycylglycine and glycinamide," Journal of the Chemical Society, Dalton Transactions, no. 1, pp. 15-17, 1977.

[24] A. Shoukry, T. Rau, M. Shoukry, and R. van Eldik, "Kinetics and mechanisms of the ligand substitution reactions of bis(amine)(cyclobutane-1,1-dicarboxylato)palladium(II)," Journal of the Chemical Society, Dalton Transactions, no. 18, pp. 3105-3112, 1998.

[25] M. A. Jakupec, M. Galanski, V. B. Arion, C. G. Hartinger, and B. K. Keppler, "Antitumour metal compounds: more than theme and variations," Dalton Transactions, no. 2, pp. 183194, 2008.

[26] H. Sigel, S. S. Massoud, and N. Acorfu, Journal of the American Chemical Society, vol. 116, p. 959, 1994.

[27] T. Soldatović, M. Shoukry, R. Puchta, Z. D. Bugarčić, and R. ven Eldik, "Equilibrium and kinetic studies of the reactions between aqua[1-(2- aminoethyl)piperazinejpalladium(II) and biologically relevant nucleophiles," European Journal of Inorganic Chemistry, no. 15, pp. 2261-2270, 2009.

[28] R. W. Hay and A. K. Basak, Journal of the Chemical Society, Dalton Transactions, p. 1821, 1982.

[29] M. M. Shoukry, E. M. Khairy, and A. Saeed, "Hydrolysis of $\alpha$ amino acid esters in ternary complexes of copper(II) involving glycyl-DL-valine," Transition Metal Chemistry, vol. 13, no. 2, pp. 146-149, 1988. 


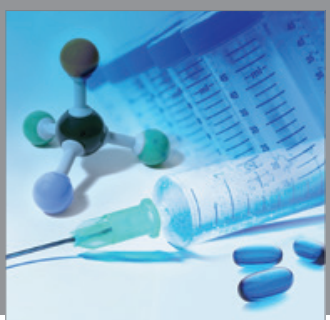

International Journal of

Medicinal Chemistry

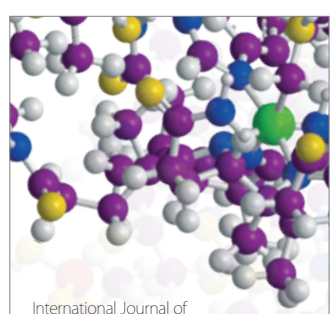

Carbohydrate Chemistry

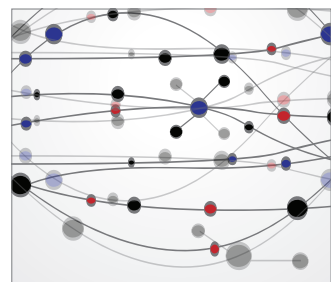

The Scientific World Journal
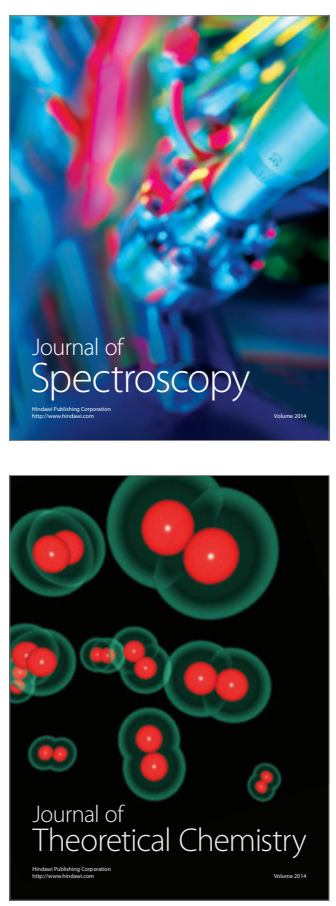
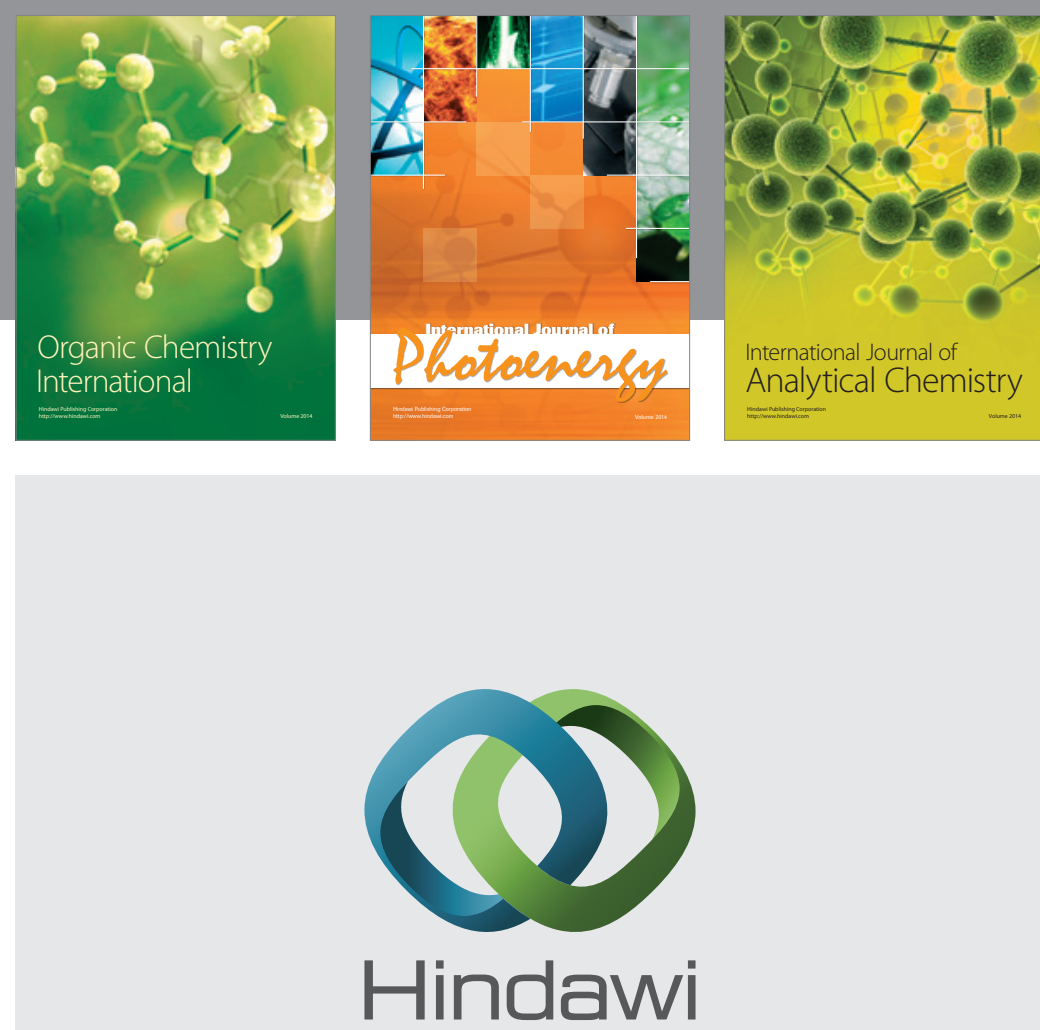

Submit your manuscripts at

http://www.hindawi.com
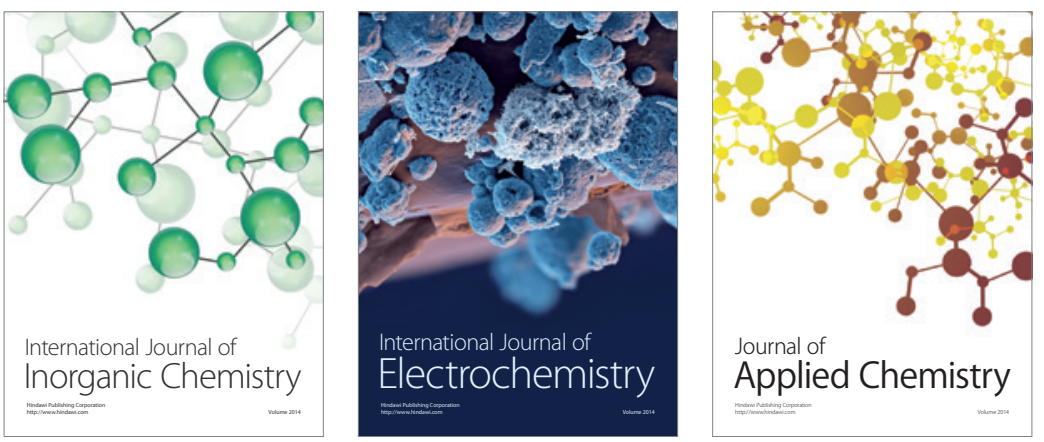

Journal of

Applied Chemistry
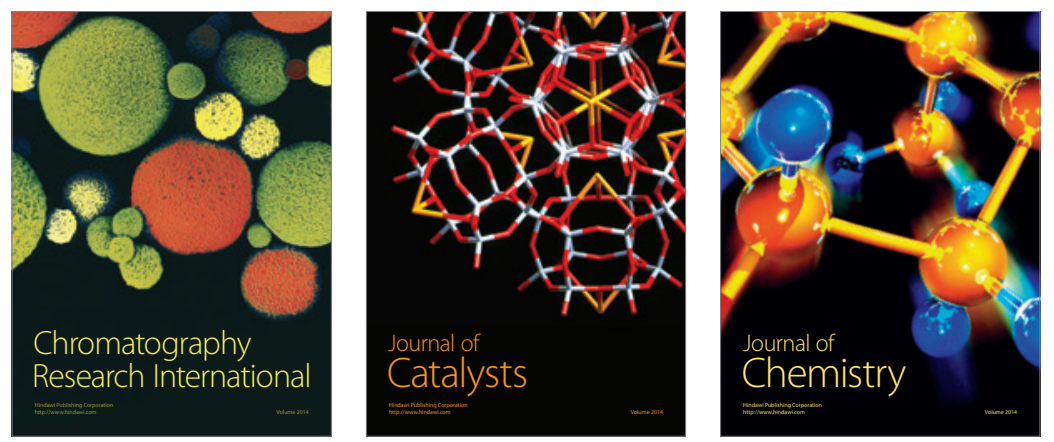
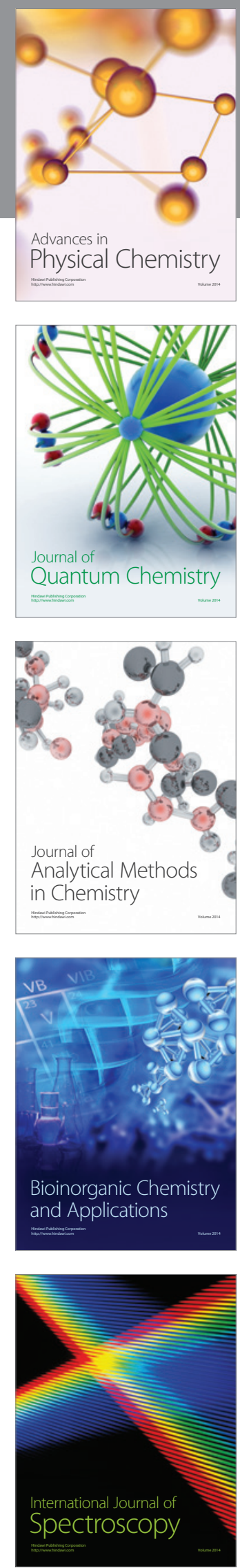